Article

\title{
Qualitative Methods and Hybrid Maps for Spatial Perception with an Example of Security Perception
}

\author{
Mandy Töppel ${ }^{1, *}$ and Christian Reichel ${ }^{2}$ \\ ${ }^{1}$ Dynamics of Communication, Knowledge and Spatial Development, Leibniz Institute for Research on Society and Space, \\ 15537 Erkner, Germany; E-Mail: mandy.toeppel@leibniz-irs.de \\ 2 Environmental Policy Research Centre, Freie Universität Berlin, 14195 Berlin, Germany; \\ E-Mails: christian.reichel@fu-berlin.de \\ * Corresponding author
}

Submitted: 31 August 2020 | Accepted: 5 November 2020 | Published: 24 February 2021

\begin{abstract}
The security/insecurity of our cities has become the subject of public debate in recent years. Intuitive concerns about safety or the lack thereof, tends to alter with experience, age, gender, social status or background, in addition to physical constitution. Perceptions of space are personal, individually selective, and thus are continuously reproduced. Noting these variations, materialised factors also play a major role, e.g., recessed house entrances, dense or high hedges, poor orientation options, dark places, etc. Attributing meaning to these materialised factors, real constructs are formed which create positive or negative narratives about certain (urban) spaces, influencing the actual use and design of urban spaces. To investigate the importance attached to certain spaces, qualitative methods are required for examining socio-spatial situations, perceptual processes and attribution (Sommer \& Töppel, 2021, p. 195). Using different methods in an explorative and in-depth descriptive research phase, such as expert interviews, user observations, surveys on go-alongs, participatory mapping with detailed information on structural and spatial locations, the advantages and disadvantages of method selection are presented. Berlin's Alexanderplatz was used as a case study area to determine perceptions of security in urban areas. We confirmed that despite variations, certain subjective perceptions concerning visibility, brightness, and audibility are collective. Additionally, hybrid maps are used to explain how subjective perceptions of space, combined with 3D graphics, can alert architects and city planners to uncertainty among users of public space.
\end{abstract}

\section{Keywords}

3D planning tools; go alongs; hybrid maps; participatory mapping; spatial perception; urban resilience

\section{Issue}

This article is part of the issue "Innovations and Development in Urban Planning Scholarship and Research" edited by Thomas W. Sanchez (Virginia Tech, USA).

(C) 2021 by the authors; licensee Cogitatio (Lisbon, Portugal). This article is licensed under a Creative Commons Attribution 4.0 International License (CC BY).

\section{Introduction}

People establish relationships with public places, endowing them with meaning as a part of their lived environment. In spatial research, a noteworthy aspect is the meaning which people assign to specific places, ascribing personal meanings founded on emotional states generated by these places (e.g., Stals, Smyth, \& Ijsselsteijn, 2014, from Sommer \& Töppel, 2021, p. 197). The rela- tionship between person and place is characterised as mutually dependent, as Casey emphasises:

The relationship between self and place is not just one of reciprocal influence....but also, more radically, of constitutive coingredience: each is essential to the being of the other. In effect, there is no place without self and no self without place. (Casey, 2001, p. 684, from Sommer \& Töppel, 2021, p. 197) 
As Sommer and Töppel summarize: "Place, and therefore any lived environment, is not merely a neutral backdrop for human interactivity. It has a structure, the experience of which mould the perceptions of those living within it (Anderson, 2004; Preston, 2003; Tilly, 1994 from Sommer \& Töppel, 2021, p. 197). Edward Relph hypothesizes this connection through the model of a perceptual space, which is determined by current and imagined and remembered places" (Relph, 1976, p. 11, from Sommer \& Töppel, 2021, p. 197)." Subjective security perceptions are consequently the result of individual perception and evaluation processes and are associated with a whole range of emotions such as fear, risk, danger, intolerance, and vulnerability in relationships (Schreiber, 2011, p. 32). Individual interpretations and evaluations of urban spaces consequently influence subjective perceptions. As Sommer \& Töppel (2021, p. 198) point out: "a research challenge when investigating the connection between place and person is that their perception of a place, especially when its connected with emotions, is often not explicit communicated. Still, places are also linked with intersubjective attributions (Kühl, 2015, p. 36)." As Sommer \& Töppel (2021, p. 198) point out: "a research challenge when investigating the connection between place and person is that their perception of a place, especially when its connected with emotions, is often not explicit communicated. Still, places are also linked with intersubjective attributions (Kühl, 2015 , p. 36)." As Sommer \& Töppel (2021, p. 198) point out: "a research challenge when investigating the connection between place and person is that their perception of a place, especially when its connected with emotions, is often not explicit communicated. Still, places are also linked with intersubjective attributions (Kühl, 2015, p. 36).As Sommer and Töppel (2021, p. 198) point out: "A research challenge when investigating the connection between place and person is that their perception of a place, especially when its connected with emotions, is often not explicit communicated. Still, places are also linked with intersubjective attributions" (see also Kühl, 2015, p. 36).

The security and insecurity of cities has increasingly become a topic of public debate in recent years. Cities offer protection; as places of cultural diversity where different groups and orders meet, they also harbour risks and dangers. Certain districts, streets, or squares are constituted as criminal or insecure areas. This is expressed in terms such as ghetto, crime hotspot or no-go area (e.g., Glasze, Pütz, \& Rolfes, 2005, p. 13). A Google image search on the subject of fearful areas-as well as the relevant scientific literature on it (Hiller, 2010; Rolfes, 2015; Schubert, 2005)-provides a clear picture: the majority of the cases are deserted, sparsely lit underpasses. However, there is difficulty in approaching the issue of security. For city dwellers, it is not so much factual, statistically verifiable crime levels that cloud their opinion, but rather subjective security perceptions, i.e., based on their subjective perception of security. These can often be influenced by negative media reports. City dwellers usually assume a greater risk of becoming victims than they statistically would be (e.g., Hermannsdörfer, 2015, p. 7; Hiller, 2010, p. 2). Overall, the following factors have so far been identified in the scientific discourse (e.g., Blieffert, Floeting, Schmalfeld, \& Schröder, 2015; Born, 2009; Hiller, 2010; Müller, 2015; Rolfes, 2015; Schmidt, 2016; Wehrheim, 2012) as essential for citizens' feelings of security or insecurity: Confusing areas, e.g., due to niches in the masonry, recessed house entrances or dense and high hedges (as hiding places for possible perpetrators), poor orientation options, poor lighting, lack of social control of offensive behaviour. Dynamic factors such as a lack of neatness (vandalism, graffiti, littering) or the dominance of certain-seemingly threatening-local social groups are also mentioned.

In our article, we focused on the perception of security in public spaces regarding visibility and audibility, with a special focus on materialised elements in space and concerning the factors gender, cultural background, personal experiences. There has been no systematic inventory of structural and spatial factors and, above all, an exact characterisation and measurement of places that are perceived as insecure, but also of places that are perceived as secure. Specifically, the research gap consists of the fact that the knowledge about structural and spatial factors named and discussed in the literature is usually not taken from systematic, empirical, or social science studies. Rather, the authors refer to experiences from police practice, in particular to results of simple inspections carried out by police experts with city planners and citizens (Abt, Hempel, Henckel, Pätzold, \& Wendorf, 2014; Koskela \& Pain, 2000; Ruhne, 2003; Schreyögg, 1989; Zinganel, 2003). Exceptions include a few systematic studies on the effects of urban lighting, which, however, produced highly contradictory results (Krause, 2013, p. 12). Exact dimensions and visual data of factors perceived as potentially dangerous in urban areas were rarely collected. This is what Kamalipour, Faizi, and Memarian (2014) say, in regard to the international context, when they speak of an 'absence of morphological mapping.' The most diverse structural-spatial factors, which are typically perceived as uncertain but also as secure, were neither systematically recorded and inventoried, nor were they precisely described and measured in terms of their characteristics.

To investigate what importance people attach to a certain space, a wide variety of methods are required with which one can grasp the most diverse elements in a socio-spatial situation. With a multi-method approach including visual methods, the perceptions of citizens and experts on uncertainties and security in public spaces were collected.

In our article, we focus on the Alexanderplatz, in the heart of Berlin, to shed light on the individual methods of subjective spatial perception, drawing out their advantages and disadvantages. We aim to present tangible methods which can grasp the subjectively shaped 
perception patterns, and answer the question, how city planners and architects can obtain security assessments for a place with the help of hybrid map visualisations in a 3D planning tool.

In the following, we present the case study area Alexanderplatz and explain why this location was investigated with regard to security perceptions. Furthermore, we give an overview of the different methods to show the advantages and disadvantages of the perception of space and security. We present our results in so-called hybrid map visualisations and make clear that security perceptions of a place are intersubjectively shared regardless of age, gender and cultural background.

\section{Case Study Area Alexanderplatz}

With an area of around eight hectares, Alexanderplatz is one of the central and well-frequented squares in Berlin. The square was named after the Russian Tsar Alexander I in 1805, but already had a central function as a market and meeting place since the 17th century, especially when the first train station was built in 1882 . At this time, Alexanderplatz served more and more as a traffic junction between the old city and the workingclass and entertainment districts in the east of the city. After the destruction of the Second World War, it acquired its present form in the 1960s and 1970s with the construction of striking buildings (Engler, 2016, p. 180). It is surrounded by commercial and office buildings, a central underground and S-Bahn station with regional transport connections and a 39-story hotel. A special feature is that trams run across and stop in the square. Up to 360,000 people cross the square every day (see BerlinOnlineStadtportal, 2017). In recent years, Alexanderplatz has become a focal point of crime. The quality of use of the public space could not be increased significantly despite some efforts (e.g., sea- sonal markets). Structural measures were not implemented, but rather the Berlin police increased their presence in the square and opened a permanent police station on December 15, 2017 (see BerlinOnlineStadtportal, 2017). Just two years after the opening of the police station, the Berlin police recorded 4,352 criminal offences from January to July, 2019. Most of the registered crimes are robberies $(2,231)$, assault and robbery (469), and drug trafficking (387; Berlin.de, 2019). Alexanderplatz is an interesting case study area as it is the most visited city square in Berlin and subsequently a high-crime spot.

\section{Methods of Subjective Spatial Perception}

In the following, we present an overview of the various methods to show the advantages and disadvantages concerning the perception of space and security. We divided our empirical research into three different phases, which partly overlapped (see Figure 1): 1. an explorative phase; 2. an in-depth description phase; and 3. a data representation phase.

In the explorative phase, the user routes on Alexanderplatz were observed to gain a first impression and access to the case study area. In a next step, we carried out a questionnaire survey at different locations in the square, intending to get the first insight into the sound/acoustic quality and lighting conditions and to determine the first structural and spatial deficits. Also, expert interviews were carried out with representatives from planning and security practice to prepare go-along routes. These findings were the basis for the following in-depth description phase, intending to further investigate individual aspects that have caught our attention. To achieve this, we used the method of go-alongs with the method of thinking aloud. Structural and spatial focus areas were recorded in which uncertainties regarding lighting, sound/acoustics, and visibility

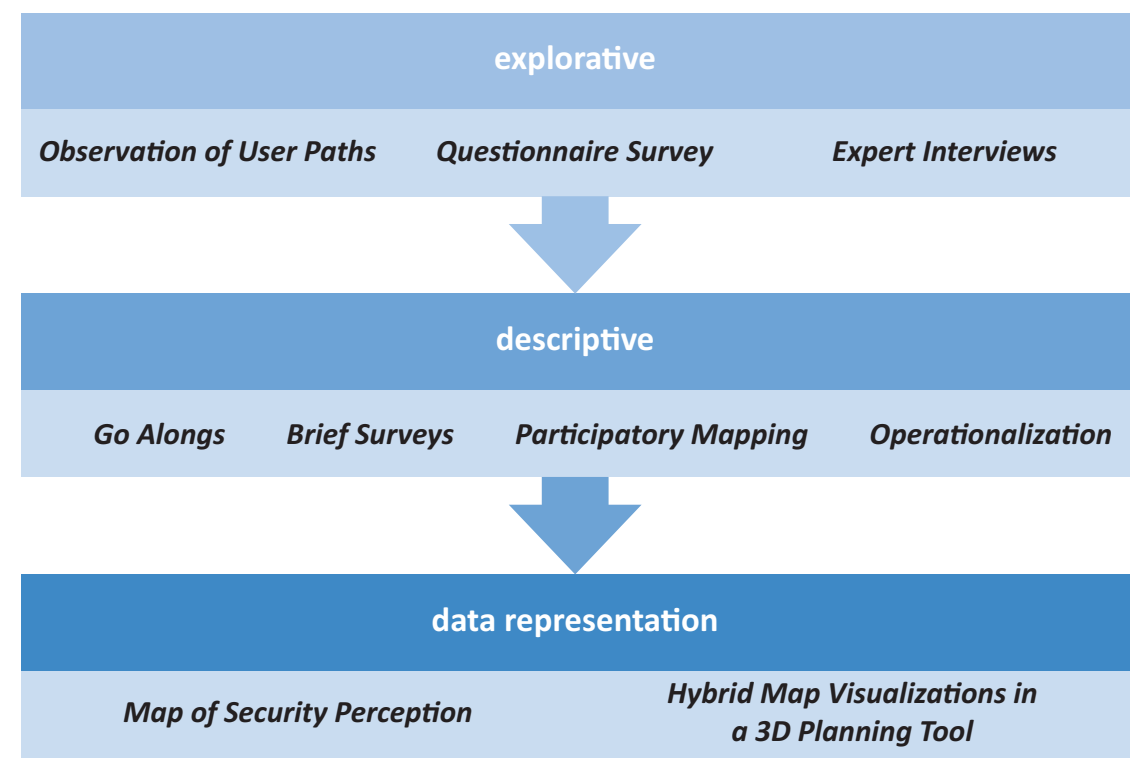

Figure 1. Overview of the three research phases and their methods for investigating spatial perceptions. 
were identified by the respondents. In addition to the go-alongs, we continued to carry out short surveys on Alexanderplatz to collect more specific information about the place. During the survey phase, several measurements of light, sound and distances of the determined structural-spatial factors were carried out to verify the respondents' statements, or to underpin their statements. Furthermore, a participatory mapping workshop took place near Alexanderplatz. In the data representation phase, we combined the evaluated results in a hybrid map visualisation for security perception. The hybrid maps are a basis for the data representation in a 3D planning tool so that actors in planning and security-practice receive security assessments.

\section{Explorative Phase}

In order to gain an insight into the case study area Alexanderplatz, the user paths in the square were observed. Also, the opportunity arose to record the light and sound conditions with students by means of a questionnaire at a certain time of day to determine the first structural-spatial factors. Through the interviews with experts, we learned more about the character of Alexanderplatz, its use, planned measures and concrete structural and spatial deficits. The initial observations and spatial perceptions of the experts from the exploratory phase were considered in the in-depth descriptive phase.

\subsection{Observation of User Paths}

In autumn 2018, we conducted observations of user paths at three locations in Alexanderplatz over two days. We did this in the mornings and afternoons to determine how the areas and their functions are being used. Another interest was to find out which space is utilised by which user groups and to deduce which users might not visit the space or possibly avoid it altogether. It is interesting to note that it is possible to determine whether certain public spaces we looked at are more transit spaces or lingering spaces. The example of Alexanderplatz has shown that the paths between the train and tram stations and the department store were the most frequented. Users tended to use the paths along the buildings and less across the square. Even while observing user routes in Alexanderplatz, a lack of convivial space usage became apparent even though the square has a lot of open space on offer. As a result, Alexanderplatz should be viewed more as a transit hub that is mainly crisscrossed by commuters and tourists and used as a transfer point. This was also evident with a view to the user groups who were less likely to be found on the site due to the observation of the user routes, such as large families and senior citizens.

The most remarkable advantage is that the method is particularly suitable for the beginning of a field phase because we were able to determine which target points in the square are highly frequented, e.g., the department stores and train station entrances and which small-scale areas are less frequented or never used. Also, in the case of longer or repeated observations, it is possible to determine how day and night differ and whether this should be taken into account in further surveys. However, one disadvantage is that we do not know why routes are being used in certain ways and have no knowledge of how these routes and their surroundings are perceived.

\subsection{Questionnaire Survey on Security Perceptions}

In June 2018, a questionnaire survey with 17 students from the disciplines of urban and regional planning as well as sociology took place at Alexanderplatz. The survey was designed to learn more about the perceptions of visibility and audibility in the square. The students were between 20 and 25 years old, 10 male and 7 females. The questionnaires were filled out at a total of $17 \mathrm{spec}-$ ified locations on and around Alexanderplatz (one student at each location). As part of the questionnaire, the students rated the lighting conditions and answered questions concerning perceptibility and direct security awareness. In parallel to the questionnaires, selective exposure measurements were carried out in order to relate the subjectively perceived lighting conditions to physical values. To systematically determine how the perception of visibility, audibility and lighting conditions changes during the transition from day to night, the questionnaires were collected in a half-hourly cycle. In the observation of the user routes, we noticed that Alexanderplatz is rather sparsely frequented after closing time. In many buildings, there are offices, which is why the own visibility by third parties in the evening hours is no longer guaranteed. One result showed the students felt less perceived by other people, while they perceived many people in the square (Figure 2).

On the one hand, the questionnaire survey has the advantage of generating a lot of collectable data in a manageable timeframe. This can then be displayed on a device showing the comparative patterns of visibility and audibility in real-time. Using this approach, we identified focus areas at Alexanderplatz and its surroundings, i.e., small-scale areas with their deficits. On the other hand, the disadvantage of questionnaires lies in their predetermined structure. Only certain aspects of perceptions can be included.

\subsection{Expert Interviews}

We initially carried out site visits and interviews with nine security experts and planning representatives who deal with the design and security of the site in a professional capacity. These were members of the police force (1), prevention officers (2), district management workers (2), architects (1), city planners (2) and landscape architects (1). The main topics of the survey were the character of the area, urban development deficits and security 


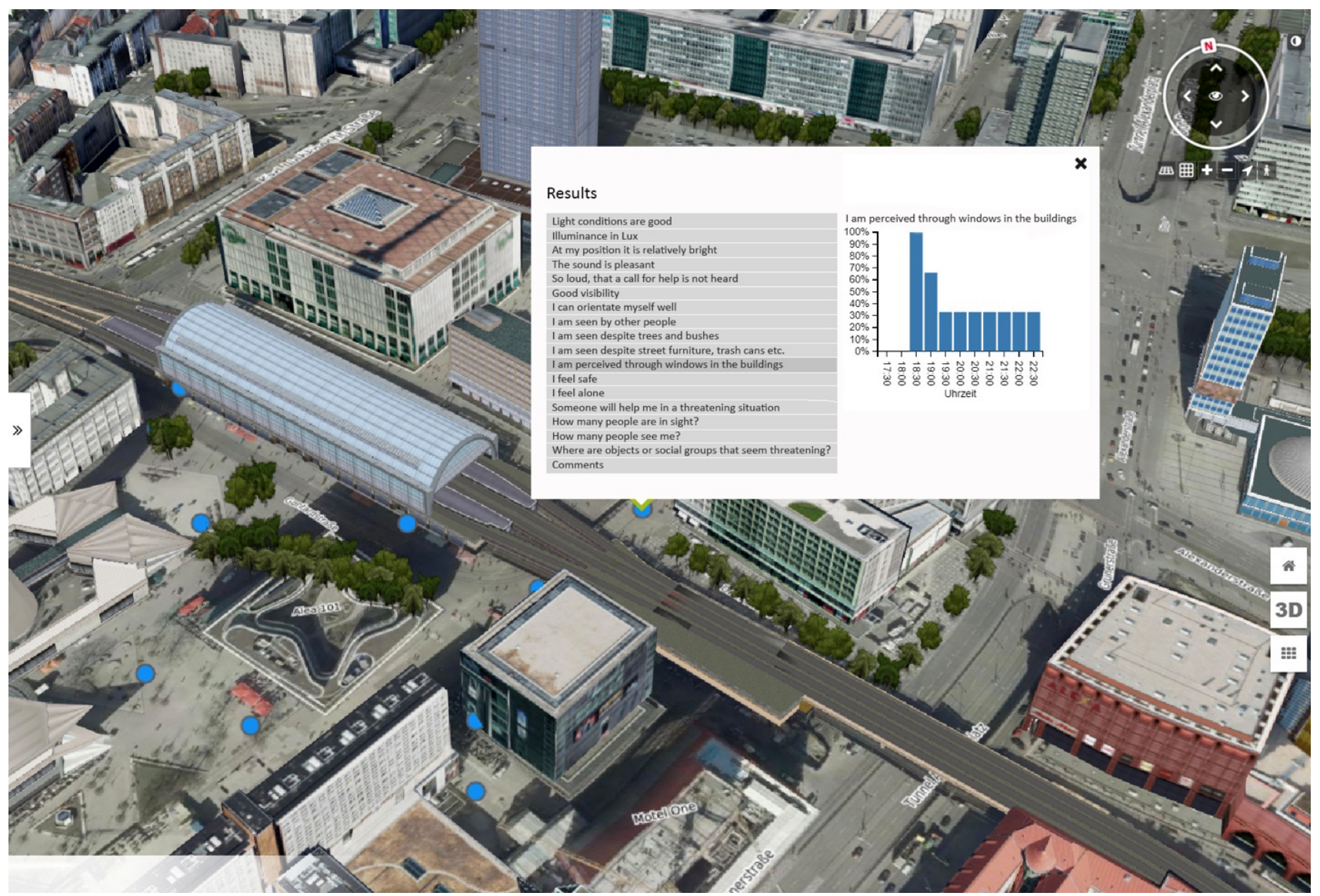

Figure 2. Questionnaire survey on security perceptions at Alexanderplatz. Source: VirtualCitySystems GmbH (Background).

perceptions, the use of space and its conflicts of use, measures and best practices. From the expert interviews, the first structural-spatial factors in the study area were determined. The following two expert statements concerning the Alexanderplatz confirm the results from the user route observation and the questionnaire collection:

So I don't know where to go, I have a few cafés on the first floor where I know they see me. With whom I can have visual contact, who I can call if something happens to me-a flower shop, a café, a newsstandwhich are practically within calling distance if something happens. I don't have that at Alexanderplatz. So a café on the square would contribute to an increased sense of security. (Expert interview, Prevention Council, District Berlin-Mitte, June 21, 2018)

It already has a large dimension, which is why this intimate feeling of being there cannot develop so easily. (Expert interview, landscape architects, May 16, 2018)

The lack of quality of stay in the square leads to a lack of visibility of oneself, which leads to a feeling of insecurity among the users. The results from the expert interviews served, among other things, as a basis for the creation of the go-along routes with the residents.
The advantage of expert interviews is that there is a higher level of knowledge, e.g., about criminal offences. Furthermore, future spatial planning projects and measures can be recorded. Consequently, the relevant research questions can only be comprehensively described in connection with expert knowledge and the everyday experience of visitors and residents. However, the experts questioned mostly work locally and have developed their own perspectives through practical work. The disadvantage is that their perception of the space is limited to a professional capacity. Differences between day and night are rarely expressed.

\section{In-Depth Description Phase}

The go-along method is fundamentally about experiencing an everyday environment and examining the perception and appropriation of spaces. Therefore, it was used in connection with the method thinking aloud to seize spatial perceptions more deeply. The short survey at Alexanderplatz was conducted to confirm or supplement the statements of the respondents from the go-alongs. When using participatory mapping, it was interesting for us to experience how users enter their perceptions on a map and which attributes they assign to them using symbols (created from the go-alongs). During the phase of the detailed description, we carried out measurements 
of light and sound in the most frequently mentioned structural-spatial areas. This enabled us to quantify the statements of the study participants and to present intersubjective perceptions of uncertainty.

\subsection{Go-Alongs}

When using go-alongs for collecting data, the focus is on the specific spatial experience during an 'interview in motion.' The researcher accompanies the respective study participants in a selected spatial environment and questions can be asked while walking (e.g., Kühl, 2015 , p. 36, from Sommer \& Töppel, 2021, p. 200). In research practice, this approach is a combination of participatory observation and qualitative interviews. According to Margarethe Kusenbach, this methodological approach eliminates the disadvantages of interviews and participant observation if the focus of analysis is on the importance of places in everyday experience (e.g., Kusenbach, 2008, p. 351, from Sommer \& Töppel, 2021 , p. 200). With participant observation, one cannot always understand all aspects of their perception and experience in the space as they usually do not verbalise their experience (e.g., Kusenbach, 2008, p. 351; Löw, 2016, p. 81, from Sommer \& Töppel, 2021, p. 201). In qualitative interviews, everyday experiences are more likely to be verbalised. This cannot always be expressed comprehensively by the respondents especially if the interview does not take place at the location itself (Kusenbach, 2008, p. 352, from Sommer \& Töppel, 2021, p. 201). The methodological challenge is transforming this everyday experience, the implied perception it contains, into spatially relevant actions, something pre- verbal or non-explicable in the investigation into spoken language. The role and presence of the researcher creates a discussion framework that offers the opportunity for personal exchange concerning experiences, impressions, and emotions on site and thus motivates the respondents to talk about their perception (e.g., Stals et al., 2014, from Sommer \& Töppel, 2021, p. 201).

\subsubsection{Applying the Go-Alongs Method}

The go-alongs were carried out with citizens of different ages, genders and from different countries of origin. They could choose their everyday route. There were suggestions from us within the respective urban area, but no further specifications. Acquiring different target groups and carrying out the investigation was, overall, very time-consuming. The go-alongs were conducted with individuals and lasted 1-2 hours. A total of 16 inspections took place between May 26, 2018 and April 17, 2019. We scheduled the go-alongs with the participants during both day and evening hours to record the different perceptions in daylight, at dusk and at night. As Sommer and Töppel (2021, p. 202) report: "During the go-alongs, we accompanied the respective participants and asked them to use the method of thinking aloud (van Someren, Barnard, \& Sandberg, 1994) to describe their perception in terms of visibility, sound/acoustic quality, observability, and brightness. So, unlike a qualitative interview, we did not lead the conversation with questions. Using the method of thinking aloud, we wanted to let the participants describe their immediate impressions to us, i.e., what was going through their heads." Participants were also asked to indicate which characteristics made them feel insecure or secure. During the go-alongs, they pointed out building structures, walls, streets, paths, squares, courtyards, parked cars, plantations and parks in terms of distances, visibility, lighting, and noise events. The reference to specific features and objects is particularly clear in the data excerpted from the Alexanderplatz case study area (Figure 3): "So here you are really surrounded by large grey buildings" (female, 26, non-resident, February 12, $2019,14: 00)$; "It is such a large space and everything is so fenced off by consumption options. You feel surrounded by all the shopping malls" (female, 26, non-resident, February 12, 2019, 14:00).

A public square like Alexanderplatz, which is surrounded by office buildings, shopping centres and hotels, offers residents and visitors little opportunity to identify with the location and makes it difficult to implement meeting places that target a wide variety of user groups to unite and promote significant social control. As a result, it remains mainly a transit space and less an inhabitable space: "A traffic junction. But without quality of stay. And that also attracts criminals" (female, 65, resident, January 7, 2019, 14.00); "Benches to sit down are in short supply" (female, 65, resident, January 7, 2019, 14.00); "Where can I meet up with friends and sit down?" (male, 40, non-resident, February 13, 2019, 16:30); "But when there's a lot going on, it's very difficult to get through here and I think the people here are pretty reckless, so everybody runs and that's why I don't like to be here unless I have to" (male, 58, resident, January 14, 2019, 15:00).

Alexanderplatz is a good example of how structural changes and different designs have assumed an overall concept over the decades, which has led to frustrations and orientation difficulties, both for visitors and residents trying to navigate the square.

As Sommer and Töppel (2021, p. 197) conclude: "For our research on the perception of security in the city, this method offered an advantage in that the perception of the spatial environment was carried out simultaneously in the concrete investigation situation and was not told to us exclusively from memory in an interview situation" (see also, e.g., Müller \& Müller, 2017, p. 54). By walking together, it is easier for the participants of a study to express themselves, through the direct connection to the environment, concerning their immediate feelings, attitudes and experiences regarding a certain place. In particular, the presence of the survey situation, which is in-situ at the specific location, can promote this effect (Sommer \& Töppel, 2001, p. 198). In this regard Kühl emphasises: 


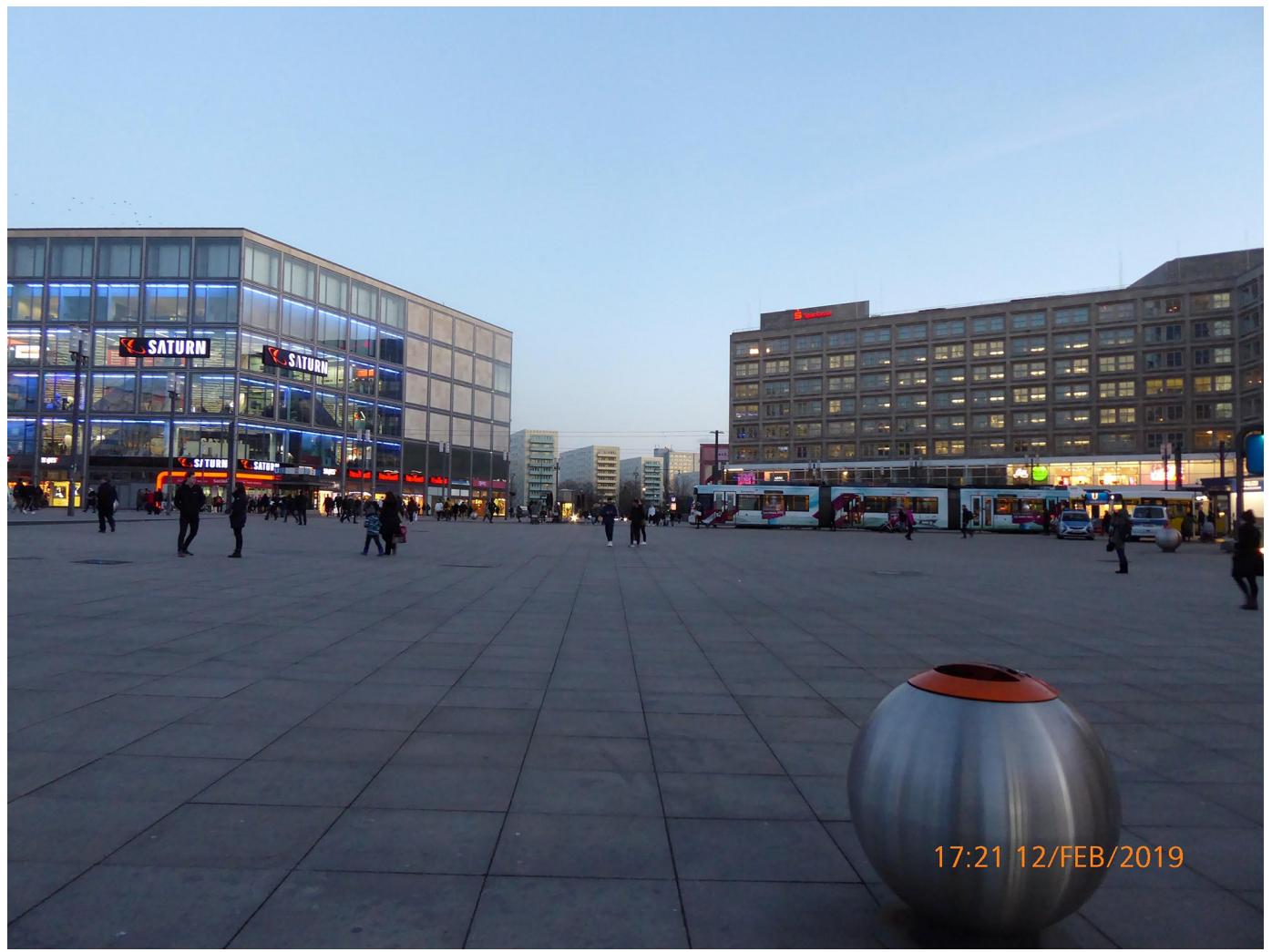

Figure 3. Alexanderplatz. Source: IRS.

Being in one place during the interview makes it possible to look at the location and to become aware of one's own experience. In concrete terms, this makes it easier for participants to reflect and verbalise thoughts, feelings, memories and other associations that are linked to and constitute the space....At the same time, concrete statements are more often made spontaneously or impulsively along with external impressions that arise depending on the situation. As a result, the spatially concrete stimulates rich explanations and expands the spectrum of the execution by aspects that would have been forgotten or detached from the context of experience. (Kühl, 2015, p. 39, after Sommer \& Töppel, 2021, p. 198; Authors' translation)

An example of the lack of orientation at Alexanderplatz clearly illustrates this: "There are no signs so that you know that I have to run here and there. If I didn't come from here, I would find it difficult" (male, 40, non-resident, February 13, 2019, 18:00); "You don't know where to go, there is no orientation" (female, 42, non-resident, March 13, 2019, 18:30); and "I definitely wouldn't find my way around here. The signage is inconspicuous" (female, 40, non-resident, February 14, 2019, 17:30).

There was often a lack of clear understanding of the Alexanderplatz space. Many areas are not differentiated and do not allow passers-by to assign functions. During a go-along, three levels can be ascertained, the level of experience, the level of current perception and the associated emotions.

As an advantage, we noted that participants were autonomous in the survey situation if they held the recording device in their own hands. Our co-presence as accompanying researchers was also another positive motivation. A conversation often resulted where respondents perceived us as experts in their urban area, yet also as interested and barely informed listeners. As a disadvantage, challenging in application is collecting the large number of statements and relevant information from the go-alongs, which have to be combined with the corresponding photos. In the analysis of the data material, therefore, priority was given to the assignment of areas and their perceptions of uncertainty and security.

\subsection{Brief Surveys on Security Perceptions}

On April 24, 2019, and May 21, 2019, short surveys of passers-by took place at Alexanderplatz. The locale was very busy on both days. A total of 26 people were asked about the structural design of Alexanderplatz and their perception of security there. Furthermore, it was ascertained how often and on what occasions which areas on the square were preferred, and which ones were avoided. Respondents were further asked how they perceived the place through the media. People surveyed included residents of retirement age as well as families on vacation and young men who only used the square as a traffic junction. The method was helpful, however, to validate 
existing assumptions about the lack of quality of staying spaces and the feeling of insecurity during the night. It was also confirmed that Alexanderplatz is used as a destination-oriented and a passing-through space. Here too, it must be emphasised that speaking about space is a methodological challenge, as Martina Löw (2016) states:

If one specifically asks about the meaning of rooms, the speakers largely fall silent. Spatial action, established connections or simply their own placements are not or only rudimentarily part of the discursive consciousness....Many spatially relevant actions take place extremely naturally and smoothly in everyday life because the knowledge of placements and synthesis is habitualised. It is precisely this inscription of knowledge into the body and materiality however, that leads to the fact that knowledge about spaces is often not explicable, nor does it appear to require naming. (Löw, 2016, p. 82; Authors' translation)

On the one hand, the short survey was advantageous in that many people could be interviewed on a limited topic in a short time to underpin or check the assessment and perception of a certain area. The method enabled us to interview people directly at the location and thus understand which material-spatial aspects triggered their attitudes, experiences and feelings. On the other hand, this method has weaknesses. The statements of the participants often remained very general and only superficial impressions were described. Our results show that short surveys cannot reflect the everyday perception that is very strongly influenced by the image of the place (e.g., via media reporting).

\subsection{Participatory Mapping}

This participative method of mapping is suitable for capturing and visualising the subjective perception and empirical knowledge of the space from the perspective of the user. At the same time, an exchange of knowledge and opinions about space is stimulated. The aim of the method is not to create a topographical representation of spatial conditions as detailed as possible but to a form of representation of how space is perceived and constructed as a result of cultural concepts, norms and ideas. Empirically valuable group discussions often arise about how these people perceive a space and which attributes they ascribe to it. This is especially true when several people are involved in a mapping process, another advantage of this method is that if a georeferenced map base is used (e.g., a topographical map or an aerial photograph), everything drawn into the map by hand can be easily transferred to a geographic information system (GIS) program or a multimedia map. Accordingly, qualitatively recorded data (such as the forms of spatial perception) can be related to quantitative data (such as the structural specifics of a location; Reichel, 2020, pp. 31-36).

\subsubsection{Participatory Mapping for Security Perceptions}

In a workshop on the perception of security in public spaces, citizens and experts spoke about their perceptions of insecurity and security in public spaces. Using the example of Alexanderplatz, the participants looked for constructive solutions that could increase the quality and the feeling of security in this square. 21 people took part in the workshop, including residents, non-residents and experts. First, the participants were asked to draw safety perceptions on transparent foils, if possible individually, based on aerial photographs of Alexanderplatz (size A0), concerning their audibility and visibility. They were then instructed to make creative suggestions for improvement. A new transparent film was placed on the aerial photograph for each participant. The security perceptions were initially mapped by colour-coding the corresponding areas. To include the reasons for their perception during the mapping, symbols were prepared in advance and created based on the (in)secure factors ascertained in the inspections. The respondents were able to place these symbols next to the feelings of security they had drawn (Figure 4). Also, during the mapping process, a log was kept of the participants' comments and sociodemographic data such as age and gender were noted.

Without the use of the symbols, compared to the results from the go-alongs, it would seem the statements about Alexanderplatz and its proximity to the train station concerning neglect, orientation, visibility, noise and the uncertainties caused by the tram on the square are congruent. The participatory mapping, on the other hand, provided specific insights into making the secure and positively perceived areas even easier to find. For this purpose, the areas near fountains and parks were all named along with the shopping malls as being suitable for relaxing and socialising.

The advantage of participatory mapping lies with its approach. Those interviewed can decide for themselves which aspects and areas on the map are important to them and which are to be neglected, and how this is to be marked. In this respect, both the finished map and the process of map creation are empirically informative. Furthermore, the method helps make questions about spatial planning more efficient, pluralistic and more democratic. This in turn leads to a higher tolerance towards the planned measures and more sustainable effectiveness of the implemented measures. The areas drawn by hand can also be easily transferred to a geographic information system program or a multimedia map. Trends in spatial perception patterns between different groups of people (e.g., broken down by age, occupation) can lead to an increase in knowledge.

However, the questions asked in our workshop about the subjective feeling of security appeared rather general and therefore not so well-suited. Without the use of the symbols, most of the feedback would have been lost. Overall, the go-alongs appeared to us to be much richer in information. 


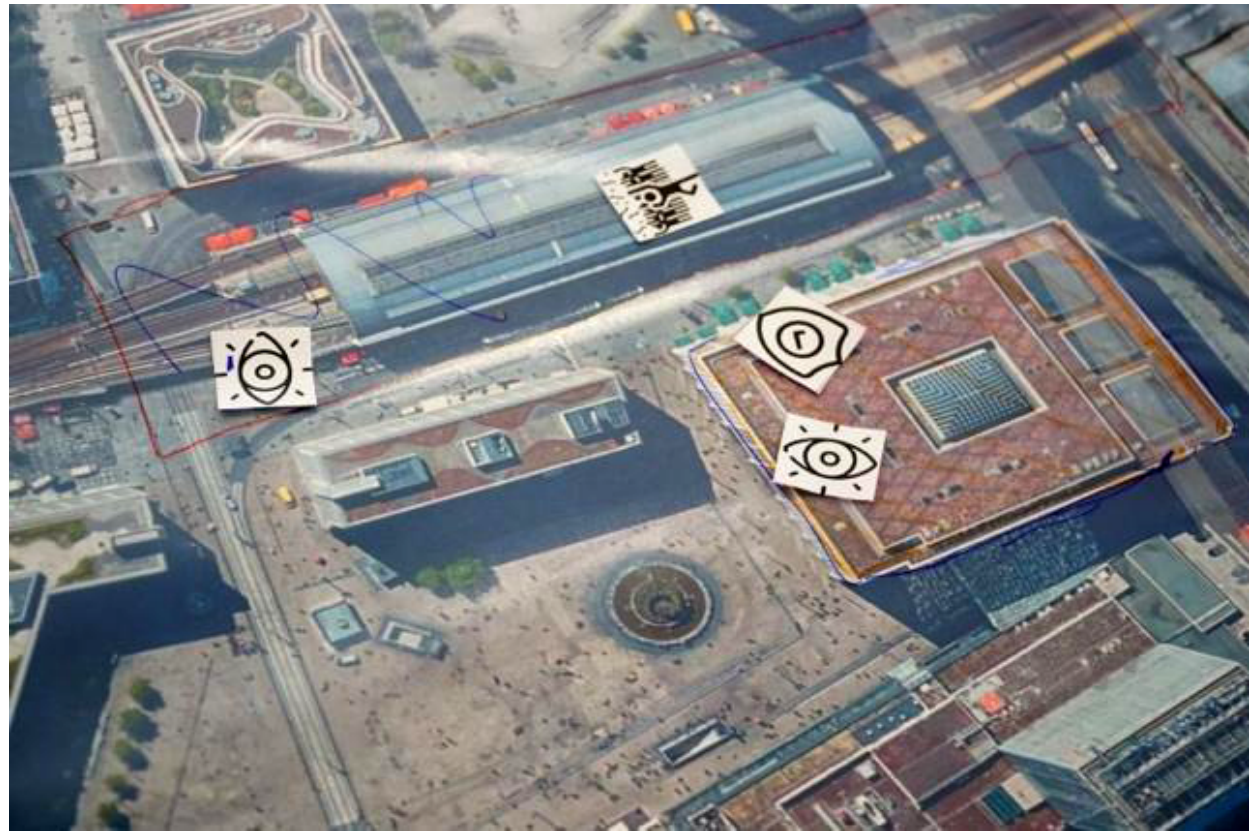

Figure 4. Participatory mapping for security perceptions. Source: IRS.

\subsection{Operationalisation of Structural and Spatial Factors}

The question of how to record the go-along process and how to prepare it for analysis is also raised. In our case, go-alongs were embedded in a multi-method research program in which, in addition to qualitative surveys, we also carried out quantitative measurements of light, sound and distances. Unlike walking-with videos (e.g., Pink, 2007), we did not record our walks on video but saved the conversations as audio recordings. As Sommer and Töppel (2021, p. 204) reported: "In addition to the audio recordings, we took photos of the features mentioned, such as a building described, and saved them with the geo-coordinates" (see also Jones, Bunce, Evans, Gibbs, \& Hein, 2008, p. 6). Based on the geo-referenced photos and the verbal statements in the course of the onsite visits, structural spatial factors that are responsible for perceptions of uncertainty could be determined as measurement locations (Figure 6). Measurements were carried out at these points to be able to assess the situation on-site at different times of the day and night and at different frequencies. Measurement data on light and sound as well as distance measurements were collected to inventory and check the relevant security perceptions.

Based on the light measurements, we can quantify the statements of the study participants, and there is the possibility of representing intersubjective uncertainty perceptions. In particular, the Fountain of Friendship between Nations in Alexanderplatz and its surroundings were perceived as 'too dark' by those surveyed. As shown in Figure 5, the fountain itself is not lit and there are large dark areas: "Compared to the rest of the square, the fountain is pretty dark. You can't even see the people sitting here" (female, 40, non-resident, February 14, 2019, 18:00).
The light measurements showed values between 3.1 and 3.6 Lux in the dark. In comparison, 1 Lux corresponds to a candle in the moonlight and 10 Lux corresponds to street lighting. The fountain is only indirectly lit by the shop windows of the surrounding shops. The alternation between light and dark areas on the square is also described as unsettling: "That's what strikes me the most-this play of light here. You always go to light places and then to dark places-dark, light, dark, light" (female, 40, non-resident, February 13, 2019, 18:00); "I'm also honestly a little shocked that nobody else is walking along here, you feel totally helpless" (female, 30, non-resident, February 12, 2019, 21:00).

A sufficient uniformity of the lighting is not guaranteed. The bright shop windows also create a glare effect. When measuring sound, we also had to determine the causes of the noise, i.e., whether it was rail noise or road traffic noise: "There is someone in front who is playing music, so if you stand here now and scream for help, you might be lucky to have someone standing next to you who understands" (male, 58, resident, February 20, $2019,15: 00)$. The audibility tests, which were carried out in places perceived to be loud, showed that a call of about 90 decibels from 20 meters could only be perceived as noise and from 25 meters could no longer be heard. As a reference, samples were taken at an inanimate place without strong ambient noise. Here, calls of about 70 decibels were perceived up to a distance of 90 meters.

On the one hand, the quantitative data (measurements of light, sound, and distances) underpin the qualitative data (uncertainty perceptions) of the study participants. One advantage is being able to use the data for calculations and representations in one tool. On the other hand, measurement inaccuracies cannot 


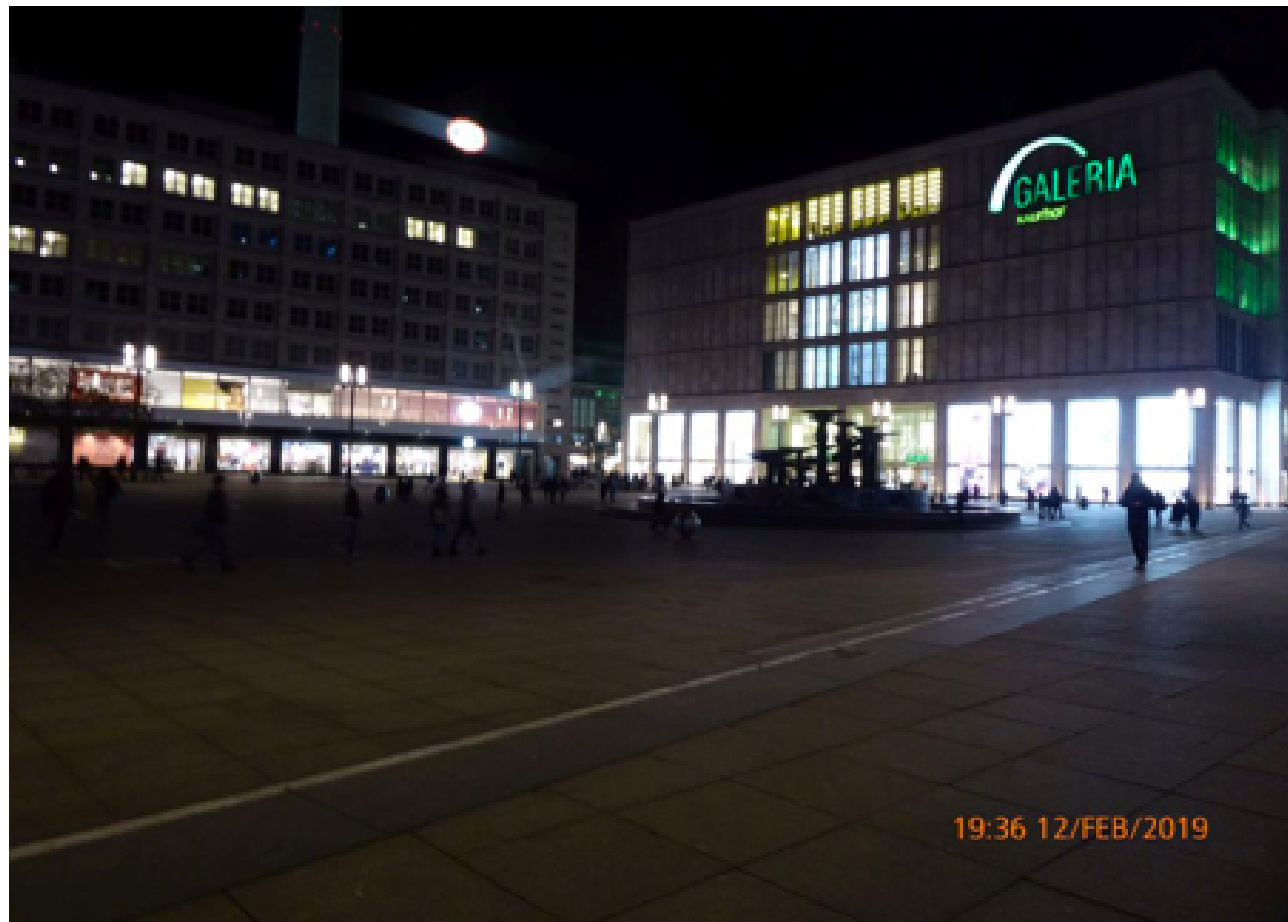

Figure 5. Fountain of Friendship between Nations at the Alexanderplatz in the dark. Source: IRS.

be excluded in the measurements of sound, light and distances. For this purpose, we performed 13 measurements on 4 different days at different times at Alexanderplatz to compare and verify the values.

\section{Data Representation}

In the data representation phase, we combined the evaluated results in a hybrid map visualisation for security perception. The hybrid maps are a basis for the data representation in a 3D planning tool so that actors in planning and security-practice receive security assessments.

\subsection{Using Georeferenced Photos to Identify Intersubjective Perception}

As already mentioned in the introduction, in the past, visual data of urban spaces perceived as potentially dangerous and their structural characteristics were rarely collected during so-called city inspections. Photographs were taken on the fringes of inspections to illustrate concrete urban fear spaces, without the photographs having been scientifically analysed and stored in GeoTools (Sommer \& Töppel, 2021, p. 204). Using a Geo-Tool (Figure 6), structural and spatial factors through georeferenced photos are identified and visualised where different participants had expressed the same perception of uncertainty. In the case study area, Alexanderplatz, three main areas were identified: the station area, the square area and the base area under the television tower. In all three focus areas, the orientation and lighting factors had the greatest impact on the respondents' perception of their security.
Consequently, the result in map view shows that the sensitivity toward security issues centring on material factors is not only subjective but shared intersubjectively. They also enable initial knowledge of the frequency of perceptions of uncertainty through the visualisation in map views. However, the georeferenced data in a map visualisation does not yet say anything concrete about the various reasons for uncertainty perceptions and must be analysed more precisely.

\subsection{Hybrid Map Visualisations}

The data from the various methods of the project were transferred to so-called hybrid maps (Figure 7). In our sense, hybrid maps are visual representations of a topic that allow different stakeholders to get the same view and understanding of a topic and to work together on it. Based on the statements and the quantitative measurements, the various socio-spatial factors assessed as insecure or secure are visualised in an integrated 3D-representation.

In the 3D-urban planning tool shown here, icons were designed to show the collected influencing factors of security perceptions, such as structural and spatial factors, the image of a place, missing offers, the infrastructure (stations, etc.), but also groups of people and social interaction. These symbols illustrate the social indications of a public space and offer the actors support in assessing security. The statements, in combination with the measurements and the representation in visualisations, resulted in comprehensive findings concerning the analysis of the perception of space, which would not have resulted without an intersection of databases and 


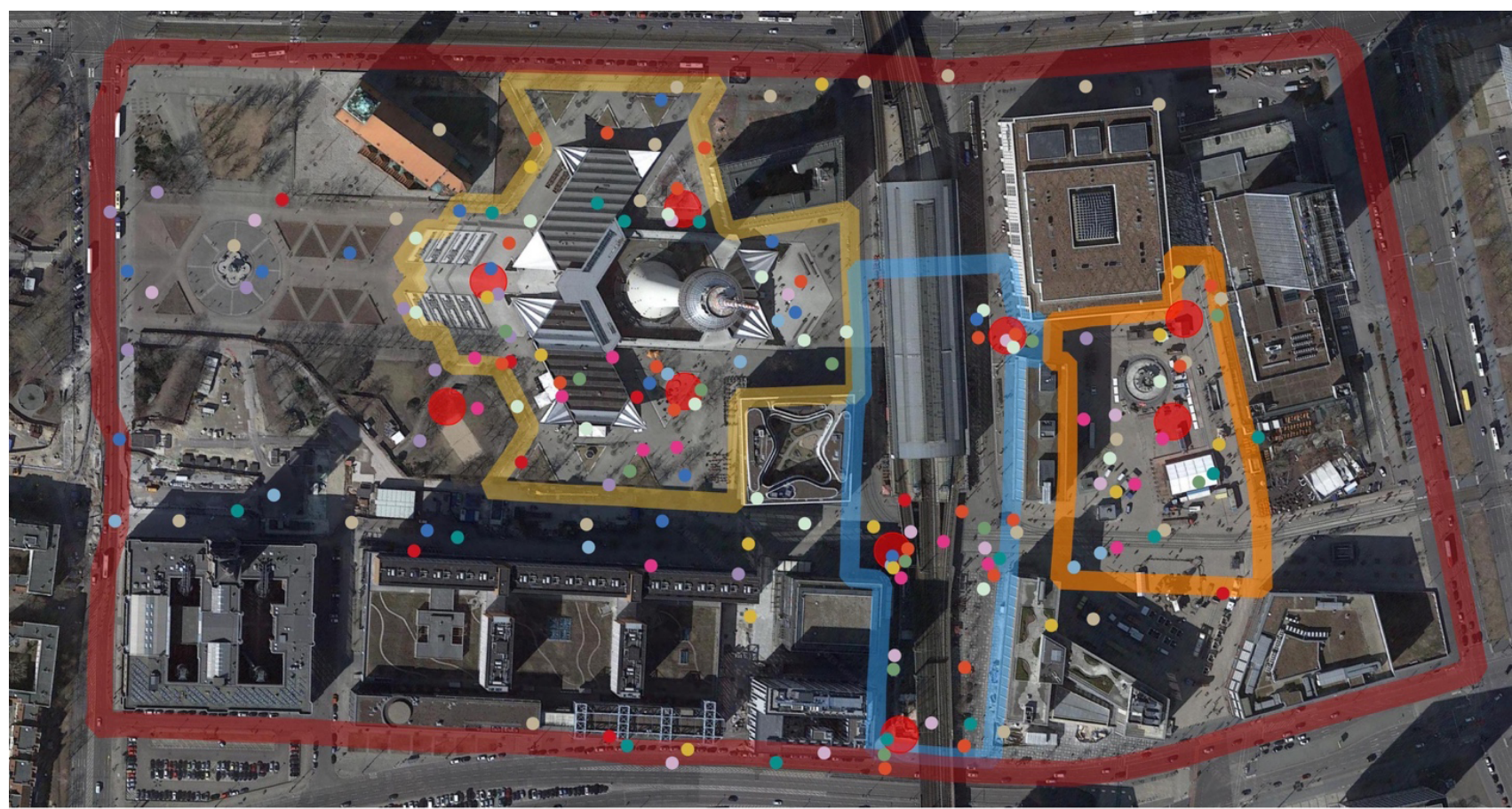

\section{Legend}

Go alongs Alexanderplatz

- 07.1.2019 14:00

0 07.1.2019 16:00

- $08.1 .201916: 30$
- $\quad 14.1 .201914: 00$

14.1.2019 16:00

- $\quad 15.1 .201915: 00$

- 24.1.2019 15:00
- 12.2.2019 14:00

- $12.2 .201918: 30$

- $\quad 13.2 .201916: 30$

- 14.2.2019 18:00

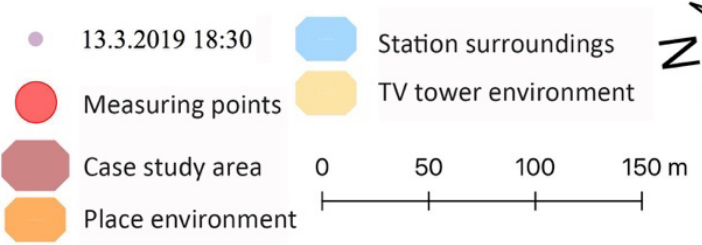

Figure 6. Map of security perception. Source: IRS.

surveys. Whether and how one combines the methods presented here always depends on the research question or the research subject and should, therefore, be appropriate to the subject.

The presentation in hybrid maps closes a gap between research and practice, as the various quantitative and qualitative data for the structural-spatial focus areas are characterised and related. However, the representation of the perceptions by icons can only be used temporarily because the perceptions of the users can be influenced by seasons, day and night times and short-lived changes on site. This form of presentation is quite new and represents an added value for experts. However, it must be considered that stereotypes and

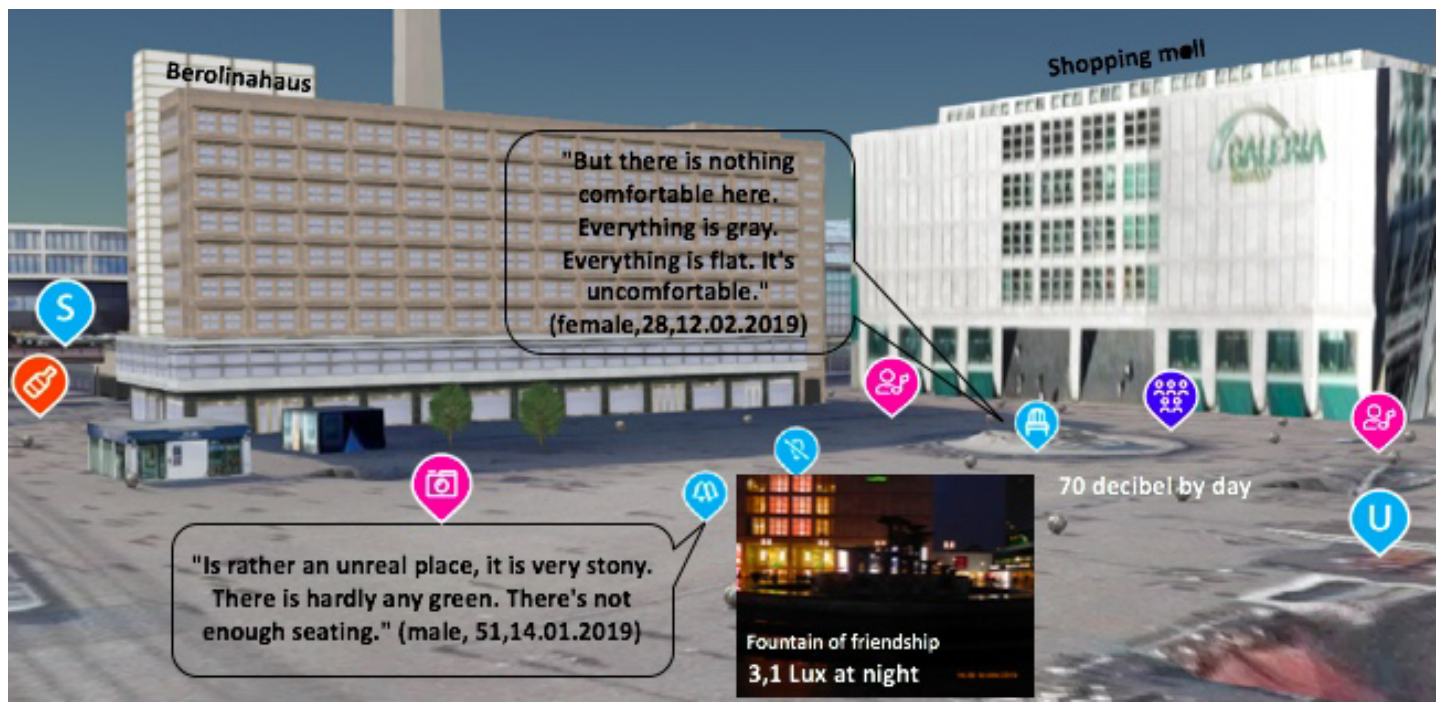

Figure 7. Hybrid map of security perception in public areas. Source: VirtualCitySystems GmbH. 
stigmatisations of a place can arise with the experts, which must be reflected exactly.

In cities, structural and spatial factors, among other things, are responsible for the (in)security perceptions of citizens, and in the future, planning practitioners will be particularly called upon to design secure urban spaces. For this purpose, a three-dimensional planning tool is being developed so that architects and planners can better recognise when a location to be planned creates uncertainties. Through 3D simulations, spatial qualities of urban planning designs can be made tangible (Gebhardt, Klemme, \& Wiegandt, 2014; Yin \& Shiode, 2014), thus enabling new forms of communicative planning, i.e., communication with and participation of stakeholders and citizens (Al-Kodmany, 2002; Billger, Thuvander, \& Wästberg, 2016, p. 7; Craig, Harris, \& Weiner, 2002; Czerkauer-Yamu \& Voigt, 2016; Müller Arisona, Aschwanden, Halatsch, \& Wonka, 2012; Silva, 2015).

\section{Conclusions}

With the methods presented here and particularly through the measurements, the perceptions, thoughts, and feelings of public spaces can be made comprehensible and substantiated. Table 1 shows a summary of the methods for collecting subjective perceptions of security in public spaces with their advantages and disadvantages, the time required for implementation, the target groups, the gain in knowledge and the possibilities for presentation in a geographic information system tool. As Sommer and Töppel point out: "With these methodological steps, our analysis of the results clearly showed that despite the different socio-demographic data and backgrounds of the respondents, certain subjective security perceptions concerning visibility, brightness, and audibility are shared. Therefore, the perception of spaces is always embedded in socio-spatial situations" (Sommer \& Töppel, 2021, p. 204).

In qualitative survey methods such as go-alongs, the user path observation and the short survey were carried out in-situ and allowed us to examine the perception of urban space for its topicality and immediacy. In our experience, these methods can be used to make perceptions, feelings and thoughts related to urban spaces comprehensible. The combination of different methods allows an empirical insight to reconstruct socio-spatial perception in everyday life on different time levels, concerning the past and the future, and in the context of impression and experience (Sommer \& Töppel, 2021, p. 206). Some of the statements of the respondents were redundant and revealed clear deficits with regard to structural and spatial factors. The respondents regularly commented on the lack of orientation and lighting and the limited quality of stay at Alexanderplatz. Particularly due to the inadequate lighting, secure movement, good spatial orientation, sufficient detail perception and early recognition of danger is even impossible. The quantitative data (measurements of light, sound and distances) underpin the qualitative data (perceptions of insecurity) of the study participants. The visualisation in map views enabled us to gain insights into the frequency of (in)security perceptions. For all the methods presented here for the subjective perception of security in urban areas and its representation in maps, the fact that the perceptions of public

Table 1. Collecting methods for subjective perceptions of security in public spaces.

\begin{tabular}{|c|c|c|c|c|c|c|c|c|c|}
\hline Categories & & User Paths & "Questionnaire" & Expert Interviews & & Go alongs & Short Survey & Participatory Mapping & Operationalization \\
\hline $\begin{array}{l}\text { Time } \\
\text { Required }\end{array}$ & & low & low & medium & & high & low & high & high \\
\hline $\begin{array}{l}\text { Watched } \\
\text { Target Groups }\end{array}$ & & $\begin{array}{l}\text { Visitors, } \\
\text { Commuters }\end{array}$ & Students & $\begin{array}{l}\text { Security Experts, } \\
\text { Urban Planners, } \\
\text { Architects }\end{array}$ & & $\begin{array}{l}\text { Residents and Non-Residents } \\
\text { of different age, gender and } \\
\text { cultural background }\end{array}$ & $\begin{array}{l}\text { Visitors, Tourists, } \\
\text { Residents }\end{array}$ & Experts and Residents & $\mathrm{x}$ \\
\hline $\begin{array}{l}\text { Advantage of } \\
\text { Perception }\end{array}$ & $\begin{array}{l}\text { e } \\
x \\
p \\
\text { l }\end{array}$ & $\begin{array}{l}\text { First insight into } \\
\text { the area to be } \\
\text { examined }\end{array}$ & $\begin{array}{l}\text { Much data on } \\
\text { perceived visibility } \\
\text { and audibility, } \\
\text { animated/invigorated }\end{array}$ & $\begin{array}{l}\text { Knowledge of spatial } \\
\text { planning data, plans } \\
\text { and measures }\end{array}$ & $\begin{array}{l}d \\
\text { e } \\
s\end{array}$ & $\begin{array}{l}\text { Perceptions of attitudes, } \\
\text { impressions, experiences } \\
\text { and feelings in relation to } \\
\text { materialized elements are } \\
\text { collected in situ. } \\
\text { Also, when and why a place } \\
\text { is avoided }\end{array}$ & $\begin{array}{l}\text { Statements about } \\
\text { the location can be } \\
\text { checked again. } \\
\text { Image of a place } \\
\text { can be determined }\end{array}$ & $\begin{array}{l}\text { The interviewees decide } \\
\text { for themselves what } \\
\text { they think is important } \\
\text { in the map }\end{array}$ & $\begin{array}{l}\text { Measurements of light } \\
\text { and sound at different } \\
\text { times of day and night } \\
\text { can provide a sound } \\
\text { basis for statements on } \\
\text { the perceptions of the } \\
\text { respondents }\end{array}$ \\
\hline $\begin{array}{l}\text { Disadvantage } \\
\text { of Perception }\end{array}$ & $\begin{array}{l}0 \\
r \\
a \\
t \\
i\end{array}$ & $\begin{array}{l}\text { No knowledge } \\
\text { about why the } \\
\text { paths are used } \\
\text { and how the } \\
\text { environment is } \\
\text { perceived }\end{array}$ & $\begin{array}{l}\text { Little in-depth } \\
\text { information on the } \\
\text { perception of security } \\
\text { through closed } \\
\text { questions. Only } \\
\text { students questioned. } \\
\text { Does not reflect } \\
\text { everyday perception }\end{array}$ & $\begin{array}{l}\text { Perception to space } \\
\text { rather professionally, } \\
\text { perception usually } \\
\text { refers to the time of } \\
\text { day on site }\end{array}$ & $\begin{array}{l}r \\
i \\
p \\
t\end{array}$ & $\begin{array}{l}\text { How many survey methods } \\
\text { an artificial arrangement, } \\
\text { which should be reflected } \\
\text { with regard to the } \\
\text { mentioned perceptions }\end{array}$ & $\begin{array}{l}\text { Does not depict } \\
\text { everyday perception }\end{array}$ & $\begin{array}{l}\text { Vulnerable groups, such } \\
\text { as homeless people or } \\
\text { young people hardly } \\
\text { use these formats, so } \\
\text { these perspectives } \\
\text { are missing }\end{array}$ & $\begin{array}{l}\text { Quantitative data only. } \\
\text { Measurements must be } \\
\text { taken several times to } \\
\text { adjust the values for } \\
\text { accuracy }\end{array}$ \\
\hline Results & $\begin{array}{l}v \\
\text { e }\end{array}$ & $\begin{array}{l}\text { Is it a transit or } \\
\text { dwelling space? } \\
\text { Which user } \\
\text { groups can be } \\
\text { found, and which } \\
\text { are missing? } \\
\text { Frequency at night } \\
\text { and day }\end{array}$ & $\begin{array}{l}\text { Small-scale areas with } \\
\text { deficits were identified }\end{array}$ & $\begin{array}{l}\text { The experts' } \\
\text { statements, in } \\
\text { conjunction with } \\
\text { the inspections and } \\
\text { mapping, can } \\
\text { answer a research } \\
\text { question more } \\
\text { comprehensively }\end{array}$ & $\begin{array}{l}\text { v } \\
\text { e }\end{array}$ & $\begin{array}{l}\text { Structural spatial factors } \\
\text { and user conflicts of the } \\
\text { location are determined }\end{array}$ & $\begin{array}{l}\text { Attitudes, } \\
\text { experiences and } \\
\text { feelings about the } \\
\text { place are recorded }\end{array}$ & $\begin{array}{l}\text { Tendencies towards } \\
\text { spatial perception } \\
\text { patters between } \\
\text { different groups of } \\
\text { people can lead to a } \\
\text { gain in knowledge }\end{array}$ & $\begin{array}{l}\text { Can substantiate the } \\
\text { statements of the } \\
\text { respondents }\end{array}$ \\
\hline $\begin{array}{l}\text { Results can } \\
\text { be displayed } \\
\text { in a 3D Tool }\end{array}$ & & $\begin{array}{l}\text { Drawings of the } \\
\text { paths can be } \\
\text { transferred }\end{array}$ & $\begin{array}{l}\text { Can be displayed } \\
\text { chronologically and } \\
\text { comparatively }\end{array}$ & $\begin{array}{l}\text { Only displayable as } \\
\text { quotations }\end{array}$ & & $\begin{array}{l}\text { Tracked routes, } \\
\text { geo-coordinates of photos } \\
\text { can be displayed }\end{array}$ & $\begin{array}{l}\text { Only displayable as } \\
\text { quotations }\end{array}$ & $\begin{array}{l}\text { The marking can be } \\
\text { transferred to a tool }\end{array}$ & $\begin{array}{l}\text { Sound, light and distance } \\
\text { measurements can be } \\
\text { displayed }\end{array}$ \\
\hline
\end{tabular}

Source: Töppel and Reichel (2020); IRS. 
space by the citizens are dependent on the seasonal changes must be taken into account, i.e., can always differ depending on the point in time. As spatial researchers, we assume an understanding of social space, but we cannot assume this perspective in the everyday perception of people. The challenge for spatial research is to make the supposed physical conditions part of the communication in the collection of data (Sommer \& Töppel, 2021, p. 195).

\section{Acknowledgments}

This research has been funded by the Federal Ministry of Education and Research (BMBF) in Germany under the "Research for civil security" program. The empirical data of this article is based on the joint project "City Security 3D" (www.stadtsicherheit-3d.de). We would like to thank all those who participated in the investigations, our former colleague Dr. Vivien Sommer and Professor Gabriela Christmann for her support.

\section{Conflict of Interests}

The authors declare no conflict of interests.

\section{References}

Abt, J., Hempel, L., Henckel, D., Pätzold, R., \& Wendorf, G. (2014). Dynamische Arrangements städtischer Sicherheit [Dynamic arrangements of urban security]. Wiesbaden: Springer VS.

Al-Kodmany, K. (2002). Visualization tools and methods in community planning. Journal of Planning Literature, 17,189-211.

Anderson, J. (2004). Talking whilst walking: A geographical archaeology of knowledge. Area 36, 3, 254-261.

BerlinOnlineStadtportal. (2017). Kriminalitätsbelastete Orte in Berlin [Crime spots in Berlin]. BerlinOnlineStadtportal. Retrieved from https://www. berlin.de/polizei/polizeimeldungen/fakten--hintergruende/artikel.597950.php

Berlin.de. (2019). Weiterhin tausende Straftaten am Alexanderplatz [Still thousands of crimes at Alexanderplatz]. Berlin.de. Retrieved from https:// www.berlin.de/aktuelles/berlin/kriminalitaet/ 5879480-4362932-weiterhin-tausende-straftatenam-alexand.html

Billger, M., Thuvander, L., \& Wästberg, B. S. (2016). In search of visualization challenges: The development and implementation of visualization tools for supporting dialogue in urban planning processes. Environment and Planning B: Planning and Design, 44(6). https://doi.org/10.1177/0265813516657341

Blieffert, H., Floeting, H., Schmalfeld, A., \& Schröder, A. (2015). Sicherheit im Wohnumfeld: Glossar [Security in the living environment: Glossary]. Berlin: Deutsches Institut für Urbanistik gGmbH.

Born, S. (2009). Kommunale Kriminalprävention in einer
Großstadt: Mehr Prävention oder mehr Repression? Eine Risiko-und Potenzialanalyse kommunaler Präventionsstrukturen in Berlin [Communal crime prevention in a megacity: More prevention or more repression? A risk and potential analysis of communal prevention structures in Berlin]. Berlin: Logos Verlag Berlin.

Casey, E. S. (2001). Between geography and philosophy: What does it mean to be in the place-world? Annals of the Association of American Geographers, 91(4), 683-693.

Craig, W. J., Harris, T. M., \& Weiner, D. (2002). Community participation and geographical information systems. London: Taylor \& Francis.

Czerkauer-Yamu, C., \& Voigt, A. (2016). Spatial simulation and the real world: Digital methods and techniques in the context of strategic planning. In P. Healey, E. A. Silva, P. Van den Broeck, \& N. Harris (Eds.), Routledge handbook of planning research methods (pp. 348-363). London: Routledge.

Engler, H. (2016). Zwischen "Alexverbot" und "Wasserklops": Gestaltung und subkulturelle Aneignung von Alexanderplatz und Breitscheidplatz in der urbanen Systemkonkurrenz Ost-und West-Berlins [Between "Alexverbot" and "Wasserklops": Design and subcultural adaptation of Alexanderplatz and Breitscheidplatz in the urban system confrontation of East and West Berlin]. In C. Bernhardt (Ed.), Städtische öffentliche Räume: Planungen, Aneignungen, Aufstände 1945-2015 [Urban public spaces: Planning, appropriation, rebellions 1945-2015] (pp. 173-212). Stuttgart: Steiner.

Gebhardt, L., Klemme, M., \& Wiegandt, C. C. (2014). Bürgerbeteiligung und Bürgerengagement in Zeiten der Digitalmoderne: drei Thesen [Citizen participation and citizen involvement in the age of digital modernity: Three theses]. disP-The Planning Review, 50, 119-128.

Glasze, G., Pütz, R., \& Rolfes, M. (2005). Die Verräumlichung von (Un-)Sicherheit, Kriminalität und Sicherheitspolitiken: Herausforderungen einer Kritischen Kriminalgeographie [The spatialization of (in)security, crime and security policy: Challenges of a Critical Criminal Geography]. In G. Glasze, R. Pütz, \& M. Rolfes (Eds.), Diskurs-Stadt-Kriminalität. Städtische (Un-)Sicherheiten aus der Perspektive von Stadtforschung und Kritischer Kriminalgeographie [Discourse-city-crime. Urban (in)securities from the perspective of urban research and critical criminal geography] (pp. 13-58). Bielefeld: transcript.

Hermannsdörfer, I. (2015). Mehr Sicherheit durch städtebauliche Kriminalprävention [More security through urban crime prevention]. In Senatsverwaltung für Stadtentwicklung und Umwelt (Ed.), Stadt der Zukunft-Stadt der Vielfalt. Urbane Sicherheit [A future city: A city of diversity. Urban Security] (pp. 5-11). Berlin: Senatsverwaltung für Stadtentwicklung und Umwelt. 
Hiller, K. (2010). Sicherheit im Stadtquartier: Angsträume und Präventionsmaßnahmen [Security in urban quarters: Anxiety spaces and prevention activities]. Stuttgart: Landeskriminalamt BadenWürttemberg. Retrieved from https://www.cima.de/ freedocs/home/7_Vortrag_LKA_Hiller_Sicherheit im_Stadtquartier.pdf

Jones, P., Bunce, G., Evans, J., Gibbs, H., \& Hein, J. R. (2008). Exploring space and place with walking interviews. Journal of Research Practice, 4(2), 1-9.

Kamalipour, H., Faizi, M., \& Memarian, G. (2014). Safe place by design: Urban crime in relation to spatiality and sociality. CUS, 2(2), 152-162.

Koskela, H., \& Pain, R. (2000). Revisiting fear and place: Women's fear of attack and the built environment. Geoforum, 31(2), 269-280.

Krause, K. (2013). Funktionen der künstlichen Beleuchtung und der Dunkelheit: Ein Bericht zum Stand der sozialwissenschaftlichen Forschung [Functions of artificial lighting and darkness: A report on the state of social science research]. Berlin: Universitätsverlag der TU Berlin.

Kühl, J. (2015). Walking Interviews als Methode zur Erhebung alltäglicher Raumproduktionen [Walking interviews as a method to survey everyday spatial productions]. Europa Regional, 23(2).

Kusenbach, M. (2008). Mitgehen als Methode Der "GoAlong" in der phänomenologischen Forschungspraxis [Going along as a method in phenomenological research practice]. In J. Raab, M. Pfadenhauer, P. Stegmaier, J. Dreher, \& B. Schnettler (Eds.), Phänomenologie und Soziologie: Theoretische Positionen, aktuelle Problemfelder und empirische Umsetzungen [Phenomenology and sociology: Theoretical positions, current problem fields and empirical realizations] (pp. 349-358). Wiesbaden: Springer VS.

Löw, M. (2016). Kommunikation über Räumen: Methodologische Überlegungen zur Analyse der Konstitution von Räumen [Communication via spaces: Methodological reflections to analyze the constitution of spaces]. In G. B. Christmann (Ed.), Zur kommunikativen Konstruktion von Räumen [The communicative construction of spaces] (pp. 79-88). Wiesbaden: Springer VS.

Müller, A., \& Müller, A. L. (2017). Der Virtual Urban Walk 3D: Eine integrative Methode zur Analyse kontextbezogener Raumwahrnehmung [The virtual urban walk 3D: An integrative method to analyze contextual spatial perception]. Europa Regional, 23(2), 49-64.

Müller, N. (2015). Kriminalprävention durch Baugestaltung [Crime prevention through architectural design] (Doctoral dissertation). Heidelberg University, Heidelberg, Germany.

Müller Arisona, S., Aschwanden, G., Halatsch, J., \& Wonka, P. (2012). Digital urban modeling and simulation. Berlin: Springer VS.

Pink, S. (2007). Walking with video. Visual Studies, 22(3), 240-252.
Preston, C. J. (2003). Grounding knowledge: Environmental philosophy, epistemology, and place. Athens, GA: The University of Georgia Press.

Reichel, C. (2020). Mensch-Umwelt-Klimawandel: Globale Herausforderungen und lokale Resilienz im Schweizer Hochgebirge [Human-environmentclimate change: Global challenges and local resilience in the Swiss mountains]. Bielefeld: transcript.

Relph, E. (1976). Place and placelessness. London: Pion Limited.

Rolfes, M. (2015). Kriminalität, Sicherheit und Raum: Humangeographische Perspektiven der Sicherheits und Kriminalitätsforschung [Crime, security and space: Human geographic perspectives of security and crime research]. Stuttgart: Franz Steiner Verlag.

Ruhne, R. (2003). Raum Macht Geschlecht [Space power gender]. Wiesbaden: Sringer VS.

Schmidt, K. (2016). Städtebau und Kriminalität: Untersuchung des Einflusses von kriminalpräventiven Erkenntnissen im Rahmen städtebaulicher Projekte in Mecklenburg-Vorpommern [Urban development and crime: Investigation of the influence of crime prevention findings in the context of urban development projects in Mecklenburg-Vorpommern]. Mönchengladbach: Forum Verlag Godesberg.

Schreiber, V. (2011). Fraktale Sicherheiten: Eine Kritik der Kommunalen Kriminalprävention [Fractal securities: A critique of communal crime prevention]. Bielefeld: transcript.

Schreyögg, F. (1989). Tatorte: Orte der Gewalt im öffentlichen Raum [Crime scenes: Places of violence in public space]. Bauwelt, 6, 196-209.

Schubert, H. (2005). Sicherheit durch Stadtgestaltung: Städtebauliche und wohnungswirtschaftliche Kriminalprävention: Konzepte und Verfahren, Grundlagen und Anwendungen [Security through urban design: Urban planning and housing crime prevention: Concepts and procedures, basics and applications]. Cologne: Verlag Sozial-Raum-Management.

Silva, C. N. (2015). Emerging issues, challenges, and opportunities in urban e-planning. Hershey: IGI Global.

Sommer, V., \& Töppel, M. (2021): Go-Alongs in einem multimethodischen Forschungsprogramm [Go-alongs in a multi-method research program]. In A. J. Heinrich, S. Marguin, A. Million, \& J. Stollmann (Eds.), Handbuch qualitative und visuelle Methoden der Raumforschung [Handbook of qualitative and visual methods of spatial research] (pp. 195-207). transcript.

Stals, S., Smyth, M., \& ljsselsteijn, W. A. (2014). Walking \& talking: Probing the urban lived experience. In V. Roto \& J. Häkkilä (Eds.), Proceedings of the NordCHI '14: The 8th Nordic conference on humancomputer interaction: Fun, fast, foundational (pp. 737-746). Helsinki, Finland.

Tilley, C. (1994). A phenomenology of landscape: Places, 
paths and monuments. Berg and Oxford: Berg Publishers.

van Someren, M., Barnard, Y., \& Sandberg, J. (1994). The think aloud method: A practical guide to modelling cognitive processes. San Diego, CA: Academic Press.

Wehrheim, J. (2012). Die überwachte Stadt: Sicherheit, Segregation und Ausgrenzung [The city under surveillance: Security, segregation and marginalization]. Opladen: Leske + Budrich.

Yin, L., \& Shiode, T. (2014). 3D spatial-temporal GIS modeling of urban environments to support design and planning processes. Journal of Urbanism: International Research on Place-Making and Urban Sustainability, 7, 152-169.

Zinganel, M. (2003). Real crime: Architektur, Stadt \& Verbrechen; zur Produktivkraft des Verbrechens für die Entwicklung von Sicherheitstechnik, Architektur und Stadtplanung [Real crime: Architecture, city \& crime; about the productive power of crime for the development of security technology, architecture and urban planning]. Vienna: Edition Selene.

\section{About the Authors}

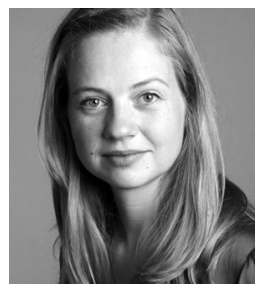

Mandy Töppel (Dipl.-Soz. tech.) is currently researching perceptions of security in urban spaces at the Leibniz Institute for Research on Society and Space. She studied sociology focussing on Science and Technology Studies (STS) at the Technische Universität Berlin. Her research interests include qualitative research methods, participation, the usability, acceptance and development of technology, especially in resilience research.

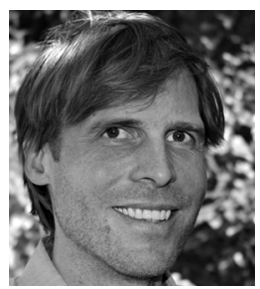

Christian Reichel (PhD) is a Researcher at the Environmental Policy Research Centre (FFU) at Freie Universität Berlin. His background is in Environmental Anthropology and Human-Geography. His work focuses on opportunities for adaptive transformations, sustainable resource use strategies and ecosystem services. 